\title{
Taxonomic notes on dubious spider species (Arachnida: Araneae) from the Russian Far East
}

\author{
Таксономические заметки о сомнительных видах пауков \\ (Arachnida: Araneae) с Аальнего Востока России
}

\author{
Rainer Breitling \\ Райнер Брейтминг
}

Faculty of Life Sciences, University of Manchester, Manchester M1 7DN, United Kingdom. E-mail: rainer.breitling@manchester.ac.uk

KEY WORDS: Araneae, revised status, nomen dubium, Far East Asia.

КЛЮЧЕВЫЕ СЛОВА: Araneae, ревизованный статус, nomen dubium, дальневосточная Азия.

ABSTRACT. The taxonomic status of six spider species described by Grube [1861] and Strand [1907] from the Russian Far East is re-examined. Asagena amurica Strand, 1907 is not a synonym of Steatoda albomaculata (De Geer, 1778), but of Asagena phalerata (Panzer, 1801) (syn.n.). Attus dimidiatus Grube, 1861 is not a synonym of Carrhotus xanthogramma (Latreille, 1819), but possibly unknown female of Mendoza zebra (Logunov et Wesołowska, 1992); in the absence of type material the name remains a nomen dubium. Attus fuscostriatus Grube, 1861 is probably a senior synonym of Talavera ikedai Logunov et Kronestedt, 2003, but until conspecific material is found from the type locality, this identification will remain uncertain. Micryphantes miniatus Grube, 1861, Linyphia albomaculata Grube, 1861, and Linyphia melanopleuros Grube, 1861, currently cannot be identified based on their original descriptions, and previously suggested synonymies are unconvincing; these taxa are also relegated again to the status of nomen dubium.

РЕЗЮМЕ. Критически проанализирован таксономический статус шести видов пауков, описанных Грубе [Grube, 1861] и Страндом [Strand, 1907] c Русского Дальнего Востока. Asagena amurica Strand, 1907 является не синонимом Steatoda albomaculata (De Geer, 1778), a Asagena phalerata (Panzer, 1801) (syn.n.). Attus dimidiatus Grube, 1861 не является синонимом Carrhotus xanthogramma (Latreille, 1819), но вероятно представляет собой неописанную самку Mendoza zebra (Logunov et Wesołowska, 1992); при отсутствии типового материала названия остается nomen dubium. Attus fuscostriatus Grube, 1861 вероятно является старшим синонимом Talavera ikedai Logunov et Kronestedt, 2003, но до тех пор, пока конспецифичный материал не собран из типового локалитета, это определение будет оставаться сомнительным. Micryphantes miniatus Grube, 1861, Linyphia albomaculata Grube, 1861 и Linyphia melanopleuros Grube, 1861 в настоящее время не могут быть идентифицированы на основе оригинальных описаний, а ранее предложенные синонимии являются неубедительными; этим таксонам возвращен статус nomen dubium.

\section{Introduction}

Numerous spider species first described in the early years of arachnology have never been found again following their initial discovery, and their identity remains unclear. In most cases, this is due to insufficient details and a lack of illustrations in the original descriptions. Often these species are listed as nomina dubia in the catalogues, i.e. "name[s] of unknown or doubtful application", whose taxonomic identity cannot be determined [ICZN, 1999]. A closer examination of such taxa can be worthwhile and is facilitated by the recent availability of full texts of a large part of the historical arachnological literature through the World Spider Catalog [2015]. A better understanding of these early arachnological records could have two major benefits. On the one hand, it could enhance nomenclatural stability. Previously, the discovery of forgotten senior synonyms regularly led to unfortunate changes in nomenclature, but the current version of the ICZN simplifies the suppression of nomina oblita and the protection of established names. Thus, the sooner senior synonyms are detected, the easier it is to take responsible action to protect a widely used name and avoid inconvenient changes later on. On the other hand, the analysis of historical spider records could potentially yield interesting faunistic insights by providing a snapshot impression of common spiders in a region in earlier times and in some cases clarifying the distributional patterns of species. Even though very small sample sizes, nonstandardized sampling protocols and usually extremely vague collection data tend to limit the information content, a combination of historical records can still be valuable (see, for instance, an analysis of the north- 
ward spread of Argiope bruennichi (Scopoli, 1772) through Europe in Sacher [2001]).

Independent of what motivates the examination of nomina dubia, a careful study of the original descriptions is necessary for it to be worthwhile. These descriptions can be very short, but they are not intentionally obscure. On the contrary, in the absence of figures, the early authors had to be particularly careful in highlighting the diagnostic habitus characters in their writings, if they wanted their species to be recognized by others. While this is unfamiliar to modern arachnologists, who tend to neglect the description of (notoriously variable) habitus characters in favour of genitalic examination, a well written description can still substantially limit the range of possible identifications and sometimes even allows an unambiguous identification based on a surprisingly concise description. This paper illustrates the potential of this approach by re-examining six historical spider records from the Russian Far East which were recently tentatively identified by Marusik et al. [2015], who formally suggested new synonymies for each of them.

\section{Material and methods}

In the absence of the type material of most of the species discussed here, the analysis is based on a careful reading of the original descriptions, as well as zoogeographical considerations, i.e., the known distribution of spider species around the type localities. Only for Asagena amurica Strand, 1907, the holotype was available for re-examination at the Zoological Museum Hamburg (despite having been reported as lost earlier [Rack, 1961]).

\section{Taxonomic survey}

Asagena amurica Strand, 1907: p. 132 = Asagena phalerata (Panzer, 1801), syn.n.

Type material. Holotype, 1 immature (Zoological Museum Hamburg); "Blagowestschensk 1884. Cordes ded. 8.XI.1894" [the city of Blagoveshchensk is the administrative centre of the Amur Area of Russia]; re-examined.

Marusik et al. [2015] considered A. amurica a junior synonym of Steatoda albomaculata (De Geer, 1778), based on an incomplete quotation from the original description [Strand, 1907: S. 134], "Abdomen schwarz, schwach rötlich angeflogen, oben mit unter sich ziemlich entfernt stehenden, gewissermassen in Reihen angeordneten, feinen graulichen Pünktchen gezeichnet, sowie mit zwei parallelen oder ganz schwach nach hinten divergierenden Reihen...", which they paraphrased as "=abdomen with two rows of dots". They neglected that the quoted sentence continues as follows: “...von je vier grösseren graulichen Punkten (Muskelpunkten)". The two rows of dots are thus only referring to the common muscle attachment sites seen in many spider species. The pattern of the opisthosoma was only described later by Strand. Concerning this pattern, Marusik et al. [2015: p. 123] stated that "Strand compared his species with $S$. phalerata and S. japonica Bösenberg et Strand, 1906 [a probable synonym of $S$. albomaculata (De Geer, 1778)]." But Strand explicitly said that Asagena amurica should differ from Asagena japonica (Dönitz et Strand) in its pattern ("Von Asagena japonica Dön. et Strand durch andere Färbung... zu unterscheiden" [Strand, 1907: S. 132]), which would argue against a synonymy with $S$. albomaculata. This assessment is confirmed by the actual description of the pattern, which consists of: two short white transverse spots in a row, separated by about their length, at the basis of the anterior end of the prosoma; one long elliptical transverse spot on each side in the middle of the abdomen, separated by about twice their longer diameter; and one white longitudinal spot at the beginning of the posterior end of the abdomen ("An der vorderen Abdachung über der Basis zwei weisse kurze Querstriche, die in ihrer Länge unter einander getrennt und in Querreihe gestellt sind. Auf dem Rücken, etwa in der Mitte, jederseits ein etwa lang ellipsenförmiger Querfleck, welche Flecke in dem doppelten ihres längsten Durchmessers getrennt sind. Am Anfang der hinteren Abdachung ein kleiner weisser Längsfleck." [Strand, 1907: S. 134]). This pattern, obviously, has no similarity with that of $S$. albomaculata, but it matches that of a juvenile Asagena phalerata. Although Strand explicitly distinguished $A$. amurica from $A$. phalerata, examination of the type material confirms this interpretation. The holotype is bleached, and the prosoma and opisthosoma are separated, but the material is otherwise in excellent condition. In contrast to the implication in Strand's description, the specimen is juvenile (not a subadult female) and even smaller than indicated in the description (prosoma $0.66 \mathrm{~mm}$, opisthosoma $0.87 \mathrm{~mm}$ ). The pattern of the opisthosoma is still visible and is in complete agreement with that of $A$. phalerata, as is the overall morphology. Any minor differences discussed in the original description can easily be explained by the juvenile state of the specimen. Published records of $A$. phalerata are known quite close to the type locality, e.g., from Kyra Distr. in the south of Transbaikalia [Logunov, Marusik 2004, cited in Danilov, 2008] and from Inner Mongolia and Jilin province in northern China [Song et al., 1999] are in favour of the synonymy as well.

Attus dimidiatus Grube, 1861: p. 179, nomen dubi$u m$, status revised

Marusik et al. [2015] considered this species a synonym of Carrhotus xanthogramma (Latreille, 1819), based on "pattern and size". The original description of A. dimidiatus [Grube, 1861: p. 179] shows, however, that this interpretation cannot be correct. A. dimidiatus was characterized by a very long and elongated opisthosoma ("maxime abdomen, elongatum", which was more slender than the prosoma ("illo angustius") and more than twice as long (3 mm vs. $1.3 \mathrm{~mm}$ ). It had a yellowish-white sternum ("sternale flavo albidum") and yel- 
low legs, chelicera and palps ("Pedes ut organa oris palpique flavi"), with three clear black spots on the upper surface, between tibia and tarsus ("supra punctis nigris inter tibiam et unguiculos positis distincti"). Moreover, the female (!) type specimen had thickened legs I ("paris $1^{\mathrm{mi}}$ ceteris crassiores"). The prosoma was yellowish horn coloured ("ochraceo-corneum"), with black central and marginal bands ("stria longitudinali ... vittaque marginali nigris"). None of these highly distinctive characters matches Carrhotus xanthogramma. They indicate a far better match to a Marpissa (subgenus Hyctius) or Mendoza species. A. dimidiatus was described from the area of Khabarovsk in the Russian Far East ("Ad flumen Amur supra ostium Ussuri”), a hotspot of the species diversity of Mendoza [Logunov 1999]. The small size of Grube's specimen (total length 4.3 $\mathrm{mm}$ ) matches only one of the Marpissa and Mendoza species known to occur in this area: Mendoza zebra (Logunov et Wesołowska, 1992), which was described based on male specimens from Khabarovsk Province and is distinguished from all other species by its noticeably smaller size [Logunov, Wesołowska, 1992]. Taking into account possible sex differences between the types of the two species, there are a number of additional habitus characters that might support this identification: both species have a rather distinct striated pattern on the prosoma, including dark median and lateral bands on a light background, which is absent or far less prominent in other species of the genus. Also, in contrast to most other Mendoza species, the thickened first pair of leg is hardly darker than the rest of the legs all of which are quite light (both descriptions refer to them as yellow) compared to other species. Also, both descriptions mention dark spots on the tibiae, which are not a prominent feature in any of the other species. The absence of transverse "zebra" stripes in $A$. dimidiatus would match the general pattern of sexual dimorphism in the genus Mendoza, with a strong dominance of longitudinal over transverse pattern elements in female specimens. However, given the diversity of Mendoza species in the area and in the absence of type material of $A$. dimidiatus, a confident identification remains impossible until authentic female specimens of Mendoza zebra have been found.

Attus fuscostriatus Grube, 1861: p. 178, nomen dubium, status revised

Marusik et al. [2015] considered this species a synonym of Neon reticulatus (Blackwall, 1853), judging "from the small size ( $3 \mathrm{~mm})$ and coloration". The original description [Grube, 1861: p. 178] shows that this identification is impossible. A. fuscostriatus had brown lateral bands and a median band that is bifurcated in front where they merge into the black ocular area ("margine laterali vittaque media antice bifurca fuscis, hac in aream ocularem nigram transeunte"). The pale grey opisthosoma had three brown longitudinal dorsal stripes and brown sides ("striis dorsi longitudinalibus 3 zonaque marginali fuscis"). The thin, brownish-white legs were annulated with narrow black rings, 4 on the front legs, 5 on the hind legs ("Pedes graciles, ex brunnescente albidi, anteriores annulis angustis nigris 4 , posteriores 5 ornati"). None of these characters matches Neon reticulatus, while they are in perfect agreement with Talavera ikedai Logunov et Kronestedt, 2003, which also shares the small size. This species has not yet been recorded from the type locality of A. fuscostriatus in the Khabarovsk area ("Ad flumen Amur supra ostium Ussuri"), but is known from South Korea and Japan as far north as Hokkaido [Logunov, Kronestedt, 2003]. The only other similar species in the area is the similarly striped Talavera trivittata (Schenkel, 1963); however, the bifurcation of the median band mentioned in the description of A. fuscostriatus seems to be the result of the "yellow median stripe on the eye field" that distinguishes $T$. ikedai from $T$. trivittata according to Logunov \& Kronestedt [2003]. Nonetheless, in the absence of the type material the species cannot yet be synonymized with confidence. This assessment may change, if material of Talavera ikedai becomes available from the Russian Far East - that this would be quite likely to happen was already indicated by Logunov \& Marusik [2000: sub Talavera sp. 4].

Linyphia albomaculata Grube, 1861: p. 166, nomen dubium, status revised

Marusik et al. [2015] considered this species a synonym of Neriene emphana (Walckenaer, 1841), based on "size and pattern, and the type locality" ["Ad sinum de Castries" = Chikhachyova Bay]. This identification is almost certainly incorrect. According to the original text [Grube, 1861: p. 167], L. albomaculata had an olive grey-brown opisthosoma with 5 white transverse bands or spots, the first three of which were more or less interrupted in the middle, while the following spots were much less broad ("Abdomen ex olivaceo griseo brunneum, supra fasciarum vel macularum transversarum albarum 5 notatum, fasciis anterioribus 3 medio plus minus interruptis, maculis sequentibus multo minus latis"). The underside was monochrome with two white longitudinal stripes ("subtus unicolor, lineis longitudinalibus albis 2"). While these are not particularly distinctive features, it is nonetheless clear that they do not match with $N$. emphana in any way, while the most striking characters of $N$. emphana, such as the black bars on the posterior end of the opisthosoma, were not mentioned. A confident alternative identification is, however, impossible due to the lack of distinct diagnostic characters and the fact that it is not even clear if the type material was a male or a female (both possibilities were mentioned in the original description). The name remains a nomen dubi$u m$, and even the generic affiliation is unclear.

Linyphia melanopleuros Grube, 1861: p. 167, nomen dubium, status revised

Marusik et al. [2015] considered this species a synonym of Megalepthyphantes nebulosus (Sundevall, 
1830), based on "size and pattern, and the distribution". The original description [Grube, 1861: p. 167] indicates that this is highly unlikely. Not only was the type of L. melanopleuros, an adult female, too small for M. nebulosus (prosoma length 11/4 mm, compared to 1.6-1.8 mm for M. nebulosus; [Nentwig et al., 2015]), but also the legs were unmarked ("pedes unicolores"), and the prosoma had a fine black margin and brown radial stripes ("subtiliter nigro marginatum, radiis fuscis adumbratis", quite in contrast to the annulated legs and prominent forked midline of the prosoma seen in $M$. nebulosus females. The very broad brown wavy band on the sides, bent down in the front and reaching the ventral area ("lateribus instita latissima sinuosa fusca ornatis, antice deflexa, in aream ventralem transeunte") that had given the species its name (melanopleuros = black-flanked) is hardly sufficiently prominent in M. nebulosus. Finally, the opisthosomal pattern of L. melanopleuros lacked the black dorsal markings that are characteristic in M. nebulosus: the dorsal surface of the opisthosoma of L. melanopleuros was simply pale grey with a broken brown medial line and irregularly scattered white spots ("supra pallide griseum, linea media fusca interrupta adumbrata, punctis albis utrinque hic illic adspersum"). While it is not unlikely that the species is synonymous with a member of Lepthyphantes sensu lato, a confident identification based on the description seems impossible at the moment.

Micryphantes miniatus Grube, 1861: p. 167, nomen dubium, status revised

Marusik et al. [2015] considered this species a synonym of Hypomma bituberculatum (Wider, 1834), based on "the prosoma coloration (red) and the size". While the cinnabar blood-red prosoma is indeed one of the most characteristic features of $M$. miniatus, it was specifically described as pale ("Cephalothorax ex miniaceo pallide sanguineum" [Grube, 1861:p. 167]), which makes the synonymy with $H$. bituberculatum somewhat doubtful; although it is safe to suspect that the material had become considerably bleached by the time it reached Grube. A number of additional diagnostic details in the original description further show that the identification by Marusik et al. [2015] is likely to be incorrect. For example, the prosoma of the female had a protruding cephalic area, half as wide as the posterior part of the prosoma ("parte capitali producta, dimidia partis posterioris latitudine") and was marked with five thin red lines that run down from the posterior eye row towards the back ("lineolis rubris 5 a serie oculorum posteriorum ortis per longitudinem decurrentibus"). Furthermore, the eyes were noticeably small ("Oculi minimi"), and the oval opisthosoma was very large, highly arched and three times as long as the prosoma ("Abdomen permagnum, ovale, alte fornicatum, 3pla cephalothoracis longitudine"). The colour of alcoholpreserved material was pale pink ("animalis alcohole servati pallide roseum"). All of these characters argue against the synonymy with $H$. bituberculatum: the prosoma of the latter is unmarked and can hardly be described as pale, its opisthosoma is grey-black, perhaps sometimes brown, but never pale pink, and even in females just before oviposition it rarely is much more than twice the length of the prosoma. A further detail that is impossible to reconcile with the synonymy with $H$. bituberculatum, and even casts doubt on the family assignment, is the fact that the spinnerets were described as distant from the rear end ("textricibus ab extremitate remotis"). Together with the large, highly arched abdomen, the pale red colour, and the protruding cephalic area, this is likely to be a member of the genus Argyrodes (Theridiidae), close to A. miniaceus (Doleschall, 1857). However, both zoogeographical arguments and other details of the habitus (especially the light red legs and the absence of any noticeable markings on the opisthosoma) make this identification speculative at best. At the moment, a confident identification of this species seems impossible, and the name remains a nomen dubium.

\section{Conclusion}

While it may be disappointing that only one of the six species discussed could be identified with confidence, and most of them have been demoted again to the status of nomen dubium, it is hoped that this analysis has not been futile. In at least one case (Attus fuscostriatus) a faunistically interesting possible identity has been revealed, which can now be followed up. And even for some of the remaining species the textual analysis has brought to light a number of rather distinct habitus features that might allow a more specific match to known species in the future - although the example of Attus fuscostriatus indicates that even historical specimens from quite small samples do not necessarily correspond to common and long-known species.

ACKNOWLEDGEMENTS. The help of Hieronymus Dastych and Thure Dalsgaard (Zoological Museum, University of Hamburg) in tracing the type material of Asagena amurica is greatly appreciated. I thank the members of the Forum of European Arachnids of the Arachnologische Gesellschaft, Germany, for introducing me to the challenges of identifying spider species based on habitus characters, and Theo Blick, Dmitri Logunov and one anonymous referee for helpful comments on the manuscript.

\section{References}

Blackwall J. 1853. Descriptions of some newly discovered species of Araneida // Annals and Magazine of Natural History. 2nd Series. Vol.11. P.14-25.

Danilov S.N. 2008. [Catalogue of the spiders (Arachnida, Aranei) of Transbaikalia]. Ulan-Ude: Buryatian Scientific Centre, Siberian Branch of the Russian Academy of Sciences Press. 108 pp. [in Russian]

De Geer C. 1778. Des Araignées // Mémoires pour servir à l'histoire des insectes. T.7. Mem.3-4. P.176-324. 
Doleschall L. 1857. Bijdrage tot de Kennis der Arachniden van den Indischen Archipel // Natuurkundig Tijdschrift voor Nederlandsch Indië. Deel 13. P.339-434.

Dönitz F.K.W., Strand E. 1906. Anhang // Bösenberg W., Strand E. Japanische Spinnen. Abhandlungen der Senckenbergischen naturforschenden Gesellschaft. Bd.30. S.93-422.

Grube A.E. 1861. Beschreibung neuer, von den Herren L. v. Schrenck, Maack, C. v. Ditmar u. a. im Amurlande und in Ostsibirien gesammelter Araneiden // Bulletin de l'Académie impériale des sciences de St.-Pétersbourg. Vol.4. P.161-180.

ICZN 1999. International Code of Zoological Nomenclature. Fourth Edition. London:The International Trust for Zoological Nomenclature. 306 pp.

Latreille P.A. 1819. Saltique // Nouveau Dictionnaire d'Histoire Naturelle. Nouvelle Édition. T.30. P.94-106.

Logunov D.V. 1999. Redefinition of the genera Marpissa C. L. Koch, 1846 and Mendoza Peckham \& Peckham, 1894 in the scope of the Holarctic fauna (Araneae, Salticidae) // Revue Arachnologique. T.13. Fasc.3. P.25-60.

Logunov D.V., Kronestedt T. 2003. A review of the genus Talavera Peckham and Peckham, 1909 (Arareae, Salticidae) // Journal of Natural History. Vol.37. No.9. P.1091-1154.

Logunov D.V., Marusik Yu.M. 2000. Catalogue of the jumping spiders of northern Asia (Arachnida, Araneae, Salticidae). Moscow:KMK Scientific Press Ltd. 299 pp.

Logunov D.V., Marusik. Yu.M. 2004. [Order Araneae - spiders] // Dubatolov V.V. et al. (eds.). Biodiversity of the Sokhondo Nature Reserve. Arthropoda. Novosibirsk - Chita. P.41-80 [in Russian].

Logunov D.V., Wesołowska W. 1992. The jumping spiders (Araneae, Salticidae) of Khabarovsk Province (Russian Far East) // Annales Zoologici Fennici. Vol.29. P.113-146.

Lucas H. 1846. Histoire naturelle des animaux articulés // Exploration scientifique de l'Algérie pendant les années 1840, 1841, 1842. Sciences physiques, Zoologie. T.1. P.89-271.

Marusik Y.M., Mikhailov K.G., Omelko M.M. 2015. Taxonomic notes on spiders (Arachnida: Aranei) of the Russian Far East // Arthropoda Selecta. Vol.24. No.1. P.117-124.
Nentwig W., Blick T., Gloor D., Hänggi A., Kropf C. 2015. Araneae - Spiders of Europe. Version 03.2015, online at http:// www.araneae.unibe.ch (accessed April 24, 2015).

Panzer G.W.F. 1801. Faunae insectorum germaniae initia, oder Deutschlands Insecten. Felseckersche Buchhandlung: Regensburg: H.78. Tab.21.

Rack G. 1961. Die Entomologischen Sammlungen des Zoologischen Staatsinstituts und Zoologischen Museums Hamburg. II. Teil, Chelicerata II: Araneae // Mitteilungen des Hamburger Zoologischen Museums und Instituts. Bd.59. S.1-60.

Sacher P. 2001. Zur Arealerweiterung von Argiope bruennichi (Araneae: Araneidae) in Deutschland - wie genau sind unsere frühen Daten? // Arachnologische Mitteilungen. Bd.22. S.2936.

Schenkel E. 1963. Ostasiatische Spinnen aus dem Muséum d'Histoire naturelle de Paris // Mémoires du Muséum d'Histoire Naturelle de Paris (A, Zool.). Vol.25. P.1-481.

Scopoli J.A. 1772. Observationes zoologicae // Annus Historiconaturalis. Annus V. P.70-128.

Song D.X., Zhu M.S., Chen J. 1999. The Spiders of China. Shijiazhuang: Hebei Science and Technology Publishing House. 640 pp.

Strand E. 1907. Süd- und ostasiatische Spinnen // Abhandlungen der Naturforschenden Gesellschaft zu Görlitz. Bd.25. H.2. S. 107-215.

Sundevall C.J. 1830. Svenska spindlarnes beskrifning // Bihang till Kongliga Svenska Vetenskaps-Akademiens Handlingar 1829. P.188-219.

Walckenaer C.A. 1841. Histoire naturelle des Insects. Aptères. T.2. P.1-549.

Wider F. 1834. Arachniden // Reuss A. (ed.). Zoologische Miscellen. Museum Senckenbergianum, Abhandlungen aus dem Gebiete der beschreibenden Naturgeschichte Bd.1. P.195-276.

World Spider Catalog. 2015. World Spider Catalog. Natural History Museum Bern, online at http://wsc.nmbe.ch (Version 16, accessed on April 24, 2015).

Responsible editor D.V. Logunov 